\title{
Influence of different concentration of cyanobacteria bio fertilizers and NPK fertilizer ratios on growth and volatile oil of rosemary
}

\author{
Esam Abd-Elkareem Abd-Elazeem Al-Azzony
}

\author{
Medicinal and Aromatic Plants Research Department, Horticulture Research Institute, \\ Agriculture Research Center, Giza, Egypt \\ Received: 16 Sept. 2019 / Accepted 10 Nov. 2019 / Publication date: 17 Nov. 2019
}

\begin{abstract}
Rosemary (Rosmarinus officinalis L., Family: Lamiaceae) is an important aromatic herb. The objective of this study was to investigate the influence of different concentration of cyanobacteria bio fertilizers and NPK fertilizer ratios on vegetative and root growth, NPK content and volatile oil \% as well as major compounds of rosemary essential oil, experiment was conducted at the Farm of the Faculty of Agriculture, Suez Canal University, Egypt during two successive seasons of 2016/2017. The treatments were 1 NPK 0 CB, 1 NPK 1CB, 1 NPK 2CB, 1 NPK 3CB, 2 NPK 0 CB, 2 NPK 1CB, 2 NPK 2CB, 2 NPK 3CB, 3 NPK 0 CB, 3 NPK 1CB, 3 NPK 2CB, 3 NPK 3CB, 4 NPK 0 CB, 4 NPK $1 \mathrm{CB}, 4$ NPK $2 \mathrm{CB}$ And 4 NPK 3CB. The different concentrations of cyanobacteria bio-fertilizers and NPK fertilizer ratios significantly increased vegetative growth and volatile oil\% as well as major compounds of rosemary essential oil. The optimum levels of cyanobacteria bio fertilizers and NPK fertilizer ratios for successful production were 4 NPK $1 \mathrm{CB}, 4 \mathrm{NPK} 2 \mathrm{CB}, 4 \mathrm{NPK} 3 \mathrm{CB}, 4 \mathrm{NPK} 0 \mathrm{CB}$, $3 \mathrm{NPK} 1 \mathrm{CB}$ and $3 \mathrm{NPK} 3 \mathrm{CB}$ gave the highest vegetative growth, essential oil \% and major compounds than other treatments respectively, while the lowest vegetative growth, essential oil \% and major compounds were obtained from the $1 \mathrm{NPK} 0 \mathrm{CB}, 1 \mathrm{NPK} 1 \mathrm{CB}, 1 \mathrm{NPK} 2 \mathrm{CB}, 1 \mathrm{NPK} 3 \mathrm{CB}, 2$ NPK 0 CB treatments during both seasons. On the other hand treatments $(2$ NPK 1 CB, 2 NPK 3CB and 3NPK $0 \mathrm{CB}$ ) recorded moderate values for vegetative growth, essential oil \% and major components, while the best treatment was (4 NPK 1CB) when compared with other treatments.
\end{abstract}

Keywords: Rosemary, cyanobacteria biofertilizers, NPK fertilizer, essential oil, yield

\section{Introduction}

Rosemary (Rosmarinus officinalis L., Family: Lamiaceae ) has both medicinal and aromatic properties. Herbs play an important role in maintaining human health and their extracted oils are used for many medical products (Al-Sereitia et al., 1999). The European Union has approved rosemary extract (E392) as a safe and effective natural antioxidant for food preservation (Food Standards Agency). Among the pharmacologically validated medicinal uses of rosemary are antibacterial (Bozin, et al., 2007), antidiabetic (Bakirel et al., 2008), anticancer (Che ung and Tai, 2007 and YesilCeliktas et al., 2010), improving cognitive deficits (Kennedy and Scholey 2006). The other major use of rosemary is the perfumery industry where the essential oils are employed as natural ingredients of fragrances, (Habtemariam 2016).

The use of cyanobacteria (bio-fertilizers) can improve growth and crop yield since they add organic matter to soil (Zaccaro et al., 1999 and Maqubela et al., 2009), thus improving soil structure (De Caire et al., 2000, De Cano et al., 2002, Pandey et al., 2005, Issa et al., 2007, Obana et al., 2007, Maqubela et al., 2009 and Saadatnia and Riahi 2009). The positive effect on crop yield was due to their release of various biologically active substances such as auxin, gibberellin and cytokinins (Whitton 2000 and Stirk et al., 2002), amino acids, vitamins, polypeptides, antibacterial and antifungal substances as well as polymers, especially exopolysaccharides (De Caire et al., 1997, De Cano et al., 1997and Zaccaro et al., 1999). Inorganic fertilizer exert strong influence on plant growth, development and yield (Stefano et al., 2004). The availability of sufficient growth nutrients from inorganic fertilizers lead to improve cell activities, enhance cell multiplication and enlargement as well as luxuriant growth (Fashina et al., 2002). Luxuriant growth resulting from fertilizer application leads to larger dry matter production (Obi et al., 2005) owing better uti-lization of solar

Corresponding Author: Esam Abd-Elkareem Abd-Elazeem Al-Azzony, Medicinal and Aromatic Plants Research Department, Horticulture Research Institute, Agriculture Research Center, Giza, Egypt. E-mail: esam.karm221@gmail.com 
radiation and more nutrient (Saeed et al., 2001). NPK fertilizer applications significantly increase plant height, stem girth, number of leaves, leaf area, leaf area index, dry matter accumulation and yield (Law-Ogbomo and Law-Ogbomo 2009). Previous researches pointed out that NPK increased growth and production of some aromatic plants such as, Mentha longifolia and Matricaria chamomilla (Alsafar and Al-Hassan, 2009 and Hendawy and Kalid, 2011).

The objective of this study was to investigate the influence of different concentration of cyanobacteria bio fertilizers as a partial replacement and NPK mineral fertilizer ratios on vegetative growth, NPK contents and volatile oil \% as well as major compounds of rosemary essential oil.

\section{Materials and Methods}

\section{Plant material}

Filed experiment were carried out at the Experimental Farm of the Faculty of Agriculture, Suez Canal University, Egypt during two successive seasons of 2016/2017, to study the impact of different concentration of cyanobacteria bio fertilizers $(1 \mathrm{CB}=$ spray $2.5 \mathrm{ml} / \mathrm{plant}, 2 \mathrm{CB}=$ ground $2.5 \mathrm{ml} / \mathrm{plant}$ and $3 \mathrm{CB}=$ spray + ground $2.5 \mathrm{ml} / \mathrm{plant})$ and $\mathrm{NPK}$ fertilizer ratios $(1 \mathrm{NPK}=8: 8: 8,2 \mathrm{NPK}=16: 8: 8,3 \mathrm{NPK}=$ 16:8:16 and $4 \mathrm{NPK}=16: 16: 8$ ) on vegetative and root growth, NPK content and oil percentage as well as major compounds of Rosmarinus officinalis L. essential oil. The seedlings were planted at the first of April. The chemical analysis of the used soil and irrigation water are presented in Table (A) according to the method described by Chapman, and Pratt, 1978. The tested treatments were conducted as follows:
1 NPK 0 CB
1 NPK 1 CB
1 NPK $2 \mathrm{CB}$
1 NPK 3CB
2 NPK 0 CB
2 NPK 1 CB
2 NPK $2 \mathrm{CB}$
2 NPK 3CB
3 NPK 0 CB
3 NPK 1 CB
3 NPK 2 CB
3 NPK 3CB
4 NPK 0 CB
4 NPK 1 CB
4 NPK 2 CB
4 NPK 3CB

Table A: The physical and chemical analysis of the used soil and irrigation water

\begin{tabular}{|c|c|c|c|c|c|c|c|c|c|}
\hline \multicolumn{4}{|c|}{$\begin{array}{c}\text { Particle size distribution } \\
(\%)\end{array}$} & \multicolumn{2}{|c|}{$\begin{array}{l}\text { Soluble cations } \\
\left(\text { mmolcl }^{-1}\right)\end{array}$} & \multicolumn{4}{|c|}{$\begin{array}{c}\text { Soluble anions } \\
\left(\mathrm{mmol}_{\mathrm{c}} \mathrm{l}^{-1}\right)\end{array}$} \\
\hline Sand & 91.5 & $\begin{array}{l}\text { Textural } \\
\text { class }\end{array}$ & sand & $\mathbf{K}^{+}$ & 1.60 & $\mathbf{N}(\mathbf{m g} / \mathbf{k g})$ & 7.56 & $\mathrm{CO}_{3}^{-2}$ & --- \\
\hline Silt & 4.40 & $\mathrm{pH}(1: 2.5)$ & 7.34 & $\mathbf{N a}^{+}$ & 4.00 & $\begin{array}{c}\mathbf{P} \\
(\mathbf{m g} / \mathbf{k g})\end{array}$ & 6.67 & $\mathrm{HCO}_{3}$ & 5.00 \\
\hline \multirow[t]{2}{*}{ Clay } & 1.55 & $\mathrm{EC}\left(\mathrm{dSm}^{-1}\right)$ & 2.10 & $\mathbf{M g}^{+2}$ & 3.56 & $\underset{(\mathrm{mg} / \mathrm{kg})}{\mathrm{K}}$ & 51 & CL- & 11.40 \\
\hline & & & & $\mathbf{C a}^{+2}$ & 4.62 & & & $\mathrm{SO}_{4}^{+2}$ & 4.91 \\
\hline \multicolumn{10}{|c|}{ Irrigation water } \\
\hline 0.389 & 7.44 & $\begin{array}{l}\mathbf{C a}^{2+} \\
1.81\end{array}$ & $\begin{array}{l}\mathbf{M g}^{2+} \\
1.11\end{array}$ & $\begin{array}{l}\mathrm{Na}^{+} \\
1.26\end{array}$ & $\begin{array}{l}\mathbf{K}^{+} \\
0.19\end{array}$ & $\mathrm{CO}_{3}{ }^{2-}$ & $\begin{array}{l}\mathrm{HCO}_{3} \\
2.56\end{array}$ & $\begin{array}{l}\mathbf{C L}^{-} \\
1.00\end{array}$ & $\begin{array}{l}\mathrm{SO}_{4}{ }^{2+} \\
0.13\end{array}$ \\
\hline
\end{tabular}

The source of nitrogen, phosphorus and potassium were (Ammonium nitrate $\mathrm{NH}_{4} \mathrm{NO}_{3} ; 33 \% \mathrm{~N}$, Monoammonium Phosphate $\left(\mathrm{NH}_{4}\right)_{3} \mathrm{PO}_{4} ; \mathrm{P}_{2} \mathrm{O}_{5} 61 \%+12 \% \mathrm{~N}$ and Potassium sulfate $\mathrm{K}_{2} \mathrm{SO}_{4} ; 50 \% \mathrm{~K}_{2} \mathrm{O}$, respectively). Treatments dates; the first time was after planted 2 weeks then each 7 days until before cut 15 days. Rosemary plants were harvested once time in each season at July 1st on both seasons. Then the following data were recorded

Plant height $(\mathrm{cm})$, number of branches/ plant and fresh and dry weight ( $\mathrm{g} / \mathrm{plant})$.

The N, P and $\mathrm{K}$ contents were determined in the leaves which were dried at $70^{\circ} \mathrm{C}$ for $48 \mathrm{hr}$. and ground leaves $(0.5 \mathrm{~g})$ were digested with sulphuric acid and hydrogen peroxide $\mathrm{H}_{2} \mathrm{SO}_{4} . \mathrm{H}_{2} \mathrm{O}_{2}$ according to the method of Lowther (1980) and the following determination were carried out in the digested solution to determine the following:

Nitrogen content ( $\mathbf{N} \%$ ) was determined in the digested plant material colorimetrically by Nessler's method (Chapman and Pratt, 1978).

Phosphorus content (P \%) was determined by the Vanadomolyate yellow methods given by Jackson (1973) and the intensity of color developed was measured by spectrophotometer at $405 \mathrm{~nm}$. 
Potassium content (K \%) was determined according to the method described by Jackson (1973) using Beckman Flame photometer.

Essential oil percentage was determined in the dried herb according to British Pharmacopocia (1963) by water-distillation $50 \mathrm{~g}$ of herb for 3 hours, in order to extract the essential oil. The isolated essential oils were kept at $4{ }^{\circ} \mathrm{C}$ until the gas chromatography analysis which was carried out using gas chromatography instrument stands at the Medicinal and Aromatic Plants Res. Dept., Hort. Res. Inst. with the following specifications. DsChrom 6200 Gas Chromatograph equipped with a flame ionization detector, Column: BPX-5, 5\% Phenyl (equiv.) Polysillphenylene-siloxane $30 \mathrm{~m} \times 0.25 \mathrm{~mm}$ ID x $0.25 \mu \mathrm{m}$ film., Sample size: $1 \mu \mathrm{l}$, Temperature program ramp increase with a rate of $10{ }^{\circ} \mathrm{C} / \mathrm{min}$ from $70{ }^{\circ} \mathrm{C}$ to $200{ }^{\circ} \mathrm{C}$, Detector temperature (FID): $280{ }^{\circ} \mathrm{C}$, Carrier gas: nitrogen, Flow rate: N2 $30 \mathrm{ml} / \mathrm{min}$; H2 $30 \mathrm{ml} / \mathrm{min}$; air $300 \mathrm{ml} / \mathrm{min}$. Main compounds of the volatile oils were identified by matching their retention times with those of the authentic samples injected under the same conditions. The relative percentage of each compound was calculated from the area of the peak corresponding to each compound.

\section{Statistical analysis}

The obtained data were analyzed statistically for (ANOVA) as Randomized Complete Blocks Design. The least significant differences (LSD at 5\%) of probability were calculated by a computer program (Costat, version 6.303, 2005) according to Gomez and Gomez (1984).

\section{Results}

Effect of cyanobacteria bio-fertilization and NPK fertilizer on vegetative growth characteristics

Data in Table (1) and Fig (1 and 2) showed the effect of cyanobacteria bio-fertilization and NPK fertilizer on plant height, number of branches /plant and fresh and dry weights (g. /plant) of rosemary (Rosmarinus officinalis L.) during the both seasons. As for the effect of bio-fertilization and NPK fertilizer obtained data showed that the treatments of 4 NPK 1CB, 4 NPK 2CB, 4 NPK 3CB, 4 NPK 0 CB, 3 NPK $1 \mathrm{CB}$ and 3 NPK $3 \mathrm{CB}$ gave the highest values for vegetative growth characters for the both seasons respectively while the least values for vegetative growth characteristics were obtained from the 1 NPK 0 CB treatment during both growing seasons. On the other hand treatments (2 NPK 1CB, 2 NPK 3CB and 3NPK $0 \mathrm{CB}$ ) gave moderate values for vegetative growth while the superior treatment was (4 NPK $1 \mathrm{CB}$ ) when compared with other treatments.

Table 1: Effect of cyanobacteria bio-fertilization and NPK fertilization on vegetative growth during 2016/2017 seasons.

\begin{tabular}{|c|c|c|c|c|c|c|c|c|c|c|}
\hline \multirow[b]{2}{*}{ Treatments } & \multicolumn{5}{|c|}{$1^{\text {st }}$ Season } & \multicolumn{5}{|c|}{$2^{\text {nd }}$ Season } \\
\hline & $\begin{array}{c}\text { Plant } \\
\text { high } \\
(\mathrm{cm})\end{array}$ & $\begin{array}{l}\text { Branches } \\
\text { No./plant }\end{array}$ & $\begin{array}{c}\text { Fresh } \\
\text { weight } \\
\text { (g./plant) }\end{array}$ & $\begin{array}{c}\text { Dry } \\
\text { weight } \\
\text { (g./plant) }\end{array}$ & $\begin{array}{c}\text { Dry } \\
\text { weight } \\
\text { /fresh } \\
\text { weight } \\
\text { (g./plant) }\end{array}$ & $\begin{array}{c}\text { Plant } \\
\text { high } \\
(\mathrm{cm})\end{array}$ & $\begin{array}{l}\text { Branches } \\
\text { No./plant }\end{array}$ & $\begin{array}{c}\text { Fresh } \\
\text { weight } \\
\text { (g./plant) }\end{array}$ & $\begin{array}{c}\text { Dry } \\
\text { weight } \\
\text { (g./plant) }\end{array}$ & $\begin{array}{c}\text { Dry } \\
\text { weight } \\
\text { / fresh } \\
\text { weight } \\
\text { (g./plant) }\end{array}$ \\
\hline 1NPK 0 CB & 47.33 & 30.66 & 331.66 & 95.8 & 0.29 & 34 & 22.33 & 296.73 & 78.73 & 0.26 \\
\hline 1 NPK $1 C B$ & 55.66 & 38.66 & 407.80 & 124.8 & 0.30 & 41.33 & 28.33 & 350.20 & 98.80 & 0.28 \\
\hline 1 NPK 2 CB & 49.66 & 33.33 & 361.40 & 110.5 & 0.30 & 37.00 & 28.66 & 323.20 & 88.53 & 0.27 \\
\hline 1 NPK 3CB & 53.66 & 35.33 & 377.53 & 112.8 & 0.30 & 41.66 & 26.33 & 336.60 & 91.86 & 0.27 \\
\hline 2NPK 0 CB & 56.33 & 38.66 & 421.73 & 128.8 & 0.30 & 42.66 & 28.33 & 371.10 & 114.66 & 0.31 \\
\hline 2 NPK $1 C B$ & 65.66 & 45.66 & 505.06 & 141.2 & 0.28 & 49.33 & 35.66 & 439.80 & 124.26 & 0.28 \\
\hline 2 NPK 2 CB & 57.66 & 40.33 & 452.33 & 136.2 & 0.30 & 43.33 & 31.33 & 397.20 & 107.80 & 0.27 \\
\hline 2 NPK 3CB & 59.00 & 43.00 & 471.20 & 140.7 & 0.29 & 47.33 & 34.33 & 404.61 & 118.66 & 0.29 \\
\hline 3NPK 0 CB & 69.66 & 46.66 & 499.93 & 138.0 & 0.28 & 56.00 & 38.33 & 418.20 & 129.86 & 0.31 \\
\hline 3 NPK 1CB & 76.00 & 56.33 & 557.86 & 146.2 & 0.26 & 61.33 & 45.33 & 487.40 & 134.66 & 0.28 \\
\hline 3 NPK 2 CB & 69.33 & 49.33 & 524.06 & 132.6 & 0.25 & 58.33 & 40.33 & 470.26 & 130.40 & 0.27 \\
\hline 3 NPK 3CB & 74.33 & 54.33 & 529.33 & 136.0 & 0.25 & 61.33 & 45.66 & 470.93 & 137.86 & 0.29 \\
\hline 4NPK 0 CB & 77.33 & 56.33 & 537.53 & 149.8 & 0.28 & 62.33 & 47.66 & 461.40 & 129.86 & 0.28 \\
\hline 4 NPK $1 C B$ & 87.00 & 63.00 & 634.13 & 167.1 & 0.26 & 71.33 & 54.33 & 557.06 & 163.06 & 0.29 \\
\hline 4 NPK 2 CB & 78.00 & 57.66 & 589.20 & 161.5 & 0.27 & 64.33 & 47.33 & 511.86 & 130.00 & 0.25 \\
\hline 4 NPK 3CB & 80.00 & 61.00 & 607.20 & 162.5 & 0.26 & 68.33 & 52.33 & 526.06 & 148.06 & 0.28 \\
\hline LSD .05 & 5.52 & 6.38 & 31.11 & 8.93 & 0.013 & 5.16 & 4.89 & 24.64 & 6.37 & 0.018 \\
\hline
\end{tabular}




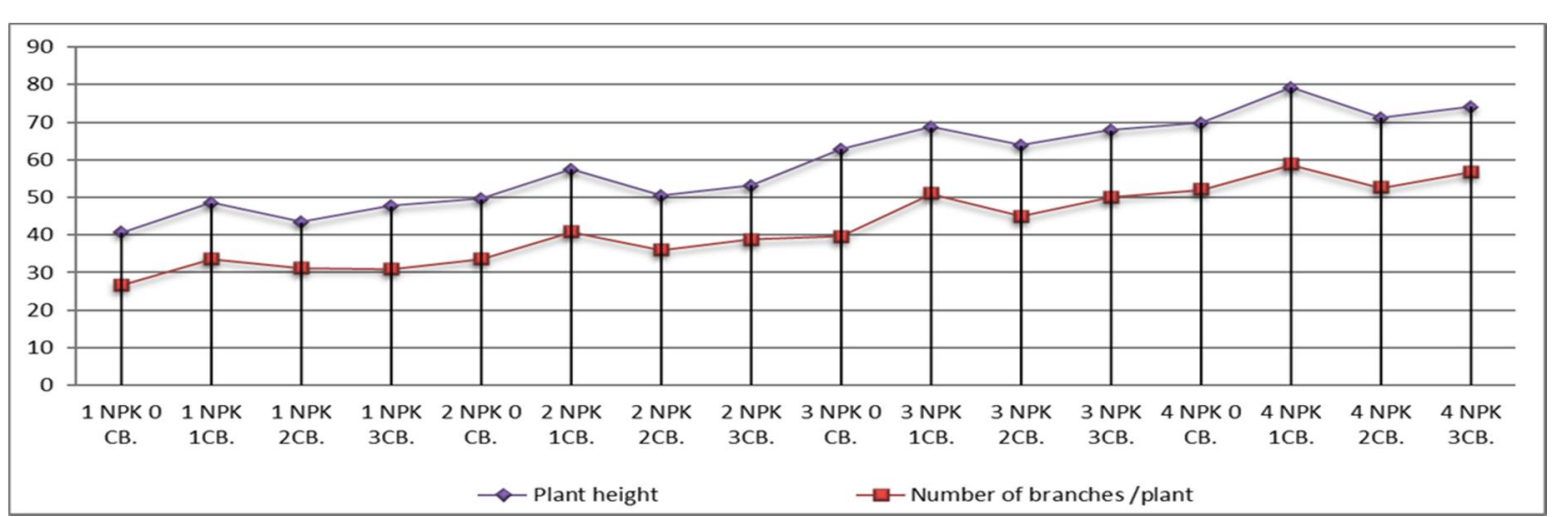

Fig. 1: Effect of cyanobacteria bio-fertilization and NPK fertilization on plant height and number of branches /plant

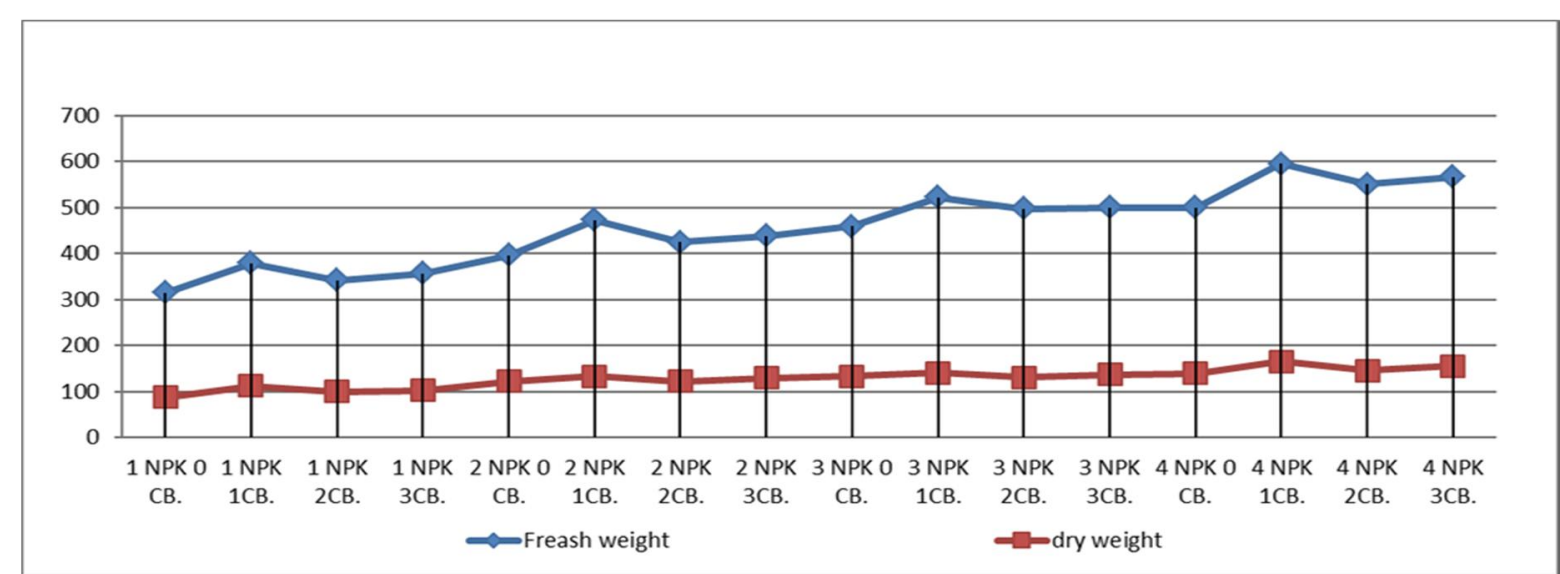

Fig. 2: Effect of cyanobacteria bio-fertilization and NPK fertilizer on fresh and dry weights (g/plant)

\section{Effect of cyanobacteria bio-fertilization and NPK fertilizer on root growth}

Root length, fresh and dry root weights of rosemary (Rosmarinus officinalis L.) were affected significantly by all the studied treatments (cyanobacteria bio-fertilization and NPK fertilizer) during the study period, (Table 2).

Table 2: Effect of cyanobacteria bio-fertilization and NPK fertilizer on root growth during 2016/2017 seasons.

\begin{tabular}{|c|c|c|c|c|c|c|}
\hline \multirow[b]{2}{*}{ Treatments } & \multicolumn{3}{|c|}{$1^{\text {st }}$ Season } & \multicolumn{3}{|c|}{$2^{\text {nd }}$ Season } \\
\hline & $\begin{array}{l}\text { Root } \\
\text { length }\end{array}$ & $\begin{array}{c}\text { Fresh } \\
\text { weight(g) }\end{array}$ & $\begin{array}{c}\text { Dry weight } \\
\text { (g) }\end{array}$ & Root length & $\begin{array}{c}\text { Fresh } \\
\text { weight(g) }\end{array}$ & $\begin{array}{c}\text { Dry } \\
\text { weight(g) }\end{array}$ \\
\hline 1 NPK 0 CB & 12.66 & 43.86 & 12.46 & 10.66 & 37.93 & 12.33 \\
\hline 1 NPK 1 CB & 19.66 & 74.933 & 20.73 & 17.66 & 66.73 & 18.60 \\
\hline 1 NPK 2 CB & 17.00 & 54.46 & 15.26 & 15.00 & 48.80 & 14.73 \\
\hline 1 NPK 3CB & 17.66 & 62.93 & 16.53 & 15.66 & 55.26 & 14.40 \\
\hline 2 NPK 0 CB & 20.66 & 92.00 & 23.66 & 18.66 & 82.40 & 21.06 \\
\hline 2 NPK $1 C B$ & 25.00 & 111.66 & 28.40 & 23.00 & 98.13 & 25.13 \\
\hline 2 NPK 2 CB & 22.66 & 99.80 & 25.33 & 19.66 & 88.73 & 23.26 \\
\hline 2 NPK 3CB & 22.00 & 107.33 & 26.53 & 19.00 & 97.06 & 24.33 \\
\hline 3 NPK 0 CB & 22.66 & 118.80 & 28.46 & 19.66 & 109.53 & 26.13 \\
\hline 3 NPK 1 CB & 27.66 & 140.60 & 37.06 & 24.66 & 125.46 & 33.00 \\
\hline 3 NPK 2 CB & 23.00 & 123.20 & 29.60 & 20.00 & 113.73 & 28.26 \\
\hline 3 NPK 3CB & 25.00 & 133.93 & 30.93 & 21.00 & 126.06 & 27.53 \\
\hline 4 NPK 0 CB & 26.33 & 158.13 & 41.73 & 22.66 & 138.00 & 37.86 \\
\hline 4 NPK $1 C B$ & 32.00 & 171.46 & 44.73 & 28.33 & 150.13 & 40.80 \\
\hline 4 NPK 2 CB & 27.33 & 163.66 & 43.26 & 23.66 & 150.86 & 37.86 \\
\hline 4 NPK 3CB & 29.00 & 161.46 & 43.33 & 25.33 & 145.33 & 40.33 \\
\hline LSD .05 & 3.63 & 13.04 & 3.36 & 3.94 & 11.11 & 3.34 \\
\hline
\end{tabular}


The untreated plants $(1 \mathrm{NPK} 0 \mathrm{CB})$ recorded the lowest values for root growth in the two seasons when compared with treated plants. The treatments (4 NPK 0 CB, 4 NPK 1CB, 4 NPK 2CB, 4 NPK $3 \mathrm{CB}, 3 \mathrm{NPK} 1 \mathrm{CB}$ ) were registered better values for root growth than the other treatments. Also, 4 NPK 1CB was the greatest treatment on increased root growth; root length and fresh and dry root weight in the current study.

\section{Effect of cyanobacteria bio-fertilization and NPK fertilization on N, P and $K \%$}

The obtained results recorded in Table (3) and Fig. (3) revealed that N, P and K\% in both seasons significantly affected by of cyanobacteria bio-fertilization and NPK fertilization. The different experimental treatments had significant increase on $\mathrm{N}, \mathrm{P}$ and $\mathrm{K}$ than control. The treatments; 4 NPK 1CB, 4 NPK 3CB, 4 NPK 2CB achieved the highest N and $\mathrm{K} \%$, while the treatments; 3 NPK $1 \mathrm{CB}, 3 \mathrm{NPK} 2 \mathrm{CB}$ and $3 \mathrm{NPK} 3 \mathrm{CB}$, recorded the highest $\mathrm{P} \%$ of rosemary herb in the two seasons than the other treatments. While treatments $2 \mathrm{NPK} 3 \mathrm{CB}, 2 \mathrm{NPK} 2 \mathrm{CB}$, and $2 \mathrm{NPK} 1 \mathrm{CB}$ gave moderate values for $\mathrm{N}, \mathrm{P}$ and $\mathrm{K} \%$.

Table 3: Effect of cyanobacteria bio-fertilization and NPK fertilizer on average N, P and $\mathrm{K} \%$ during 2016/2017 seasons.

\begin{tabular}{lccc}
\hline Treatments & N\% & P \% & K\% \\
\hline 1 NPK 0 CB & 1.316 & 0.173 & 2.090 \\
1 NPK 1CB & 1.600 & 0.246 & 2.330 \\
1 NPK 2CB & 1.483 & 0.193 & 2.160 \\
1 NPK 3CB & 1.553 & 0.213 & 2.216 \\
2 NPK 0 CB & 2.146 & 0.276 & 2.503 \\
2 NPK 1CB & 2.423 & 0.420 & 2.853 \\
2 NPK 2CB & 2.226 & 0.323 & 2.616 \\
2 NPK 3CB & 2.326 & 0.353 & 2.790 \\
3 NPK 0 CB & 2.450 & 0.623 & 3.230 \\
3 NPK 1CB & 2.703 & 0.716 & 3.533 \\
3 NPK 2CB & 2.526 & 0.716 & 3.316 \\
3 NPK 3CB & 2.650 & 0.736 & 3.473 \\
4 NPK 0 CB & 2.776 & 0.520 & 3.633 \\
4 NPK 1CB & 3.083 & 0.626 & 3.893 \\
4 NPK 2CB & 2.836 & 0.546 & 3.826 \\
4 NPK 3CB & 2.996 & 0.613 & 3.806 \\
LSD .05 & $\mathbf{0 . 1 0 5 2}$ & $\mathbf{0 . 0 4 9 7}$ & $\mathbf{0 . 2 1 7 2}$ \\
\hline
\end{tabular}

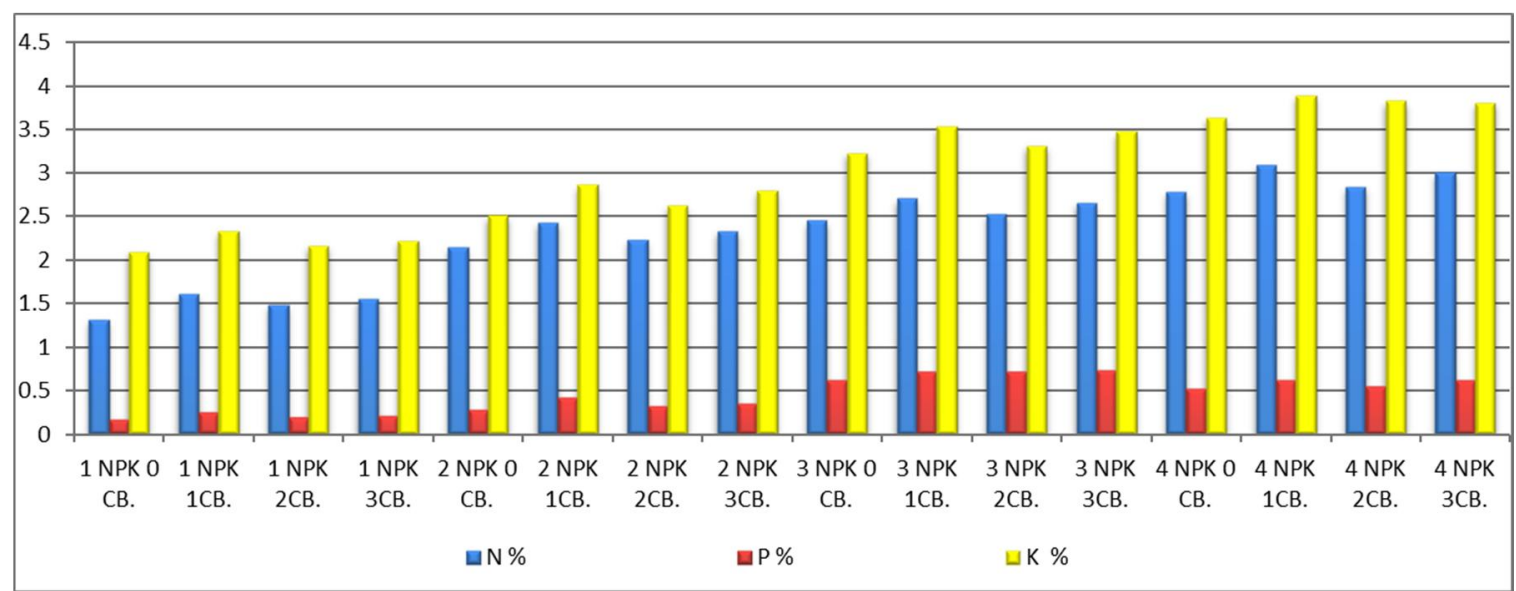

Fig. 3: Effect of cyanobacteria bio-fertilization and NPK fertilizer on N, P and K\%

\section{Effect of cyanobacteria bio-fertilization and NPK fertilizer on volatile oil \%}

The obtained data in Table (4) and Fig (4) indicate the effect of cyanobacteria bio-fertilization and NPK fertilizer on volatile oil \% in $2016 / 2017$ seasons. All treatments significantly affected on volatile oil \% in both cropping seasons than control. The highest values of volatile oil \% were recorded with the 4 NPK 1CB, 4 NPK 3CB, 4 NPK 0 CB, 4 NPK $2 \mathrm{CB}$ and 3 NPK $1 \mathrm{CB}$ as compared 
with other treatments in both seasons. In addition to the treatments; 2 NPK 1CB, 3 NPK 0 CB, 3 NPK $2 \mathrm{CB}$ and 3 NPK $3 \mathrm{CB}$ caused average effect on oil \% of rosemary herb in two seasons than the other treatments. Treatment 4 NPK 1 CB was greater than all other treatments for oil\% enhancement during study period.

Table 4: Effect of cyanobacteria bio-fertilization and NPK fertilizer on average volatile oil \% during 2016/2017 seasons.

\begin{tabular}{lc}
\hline Treatment & Oil \% \\
\hline 1 NPK 0 CB & 0.144 \\
1 NPK 1CB & 0.166 \\
1 NPK 2CB & 0.153 \\
1 NPK 3CB & 0.159 \\
2 NPK 0 CB & 0.165 \\
2 NPK 1CB & 0.188 \\
2 NPK 2CB & 0.177 \\
2 NPK 3CB & 0.181 \\
3 NPK 0 CB & 0.210 \\
3 NPK 1CB & 0.248 \\
3 NPK 2CB & 0.231 \\
3 NPK 3CB & 0.234 \\
4 NPK 0 CB & 0.269 \\
4 NPK 1CB & 0.283 \\
4 NPK 2CB & 0.267 \\
4 NPK 3CB & 0.276 \\
LSD 0.05 & $\mathbf{0 . 0 1 0 8}$ \\
\hline
\end{tabular}

$\square$ Essential oil \%

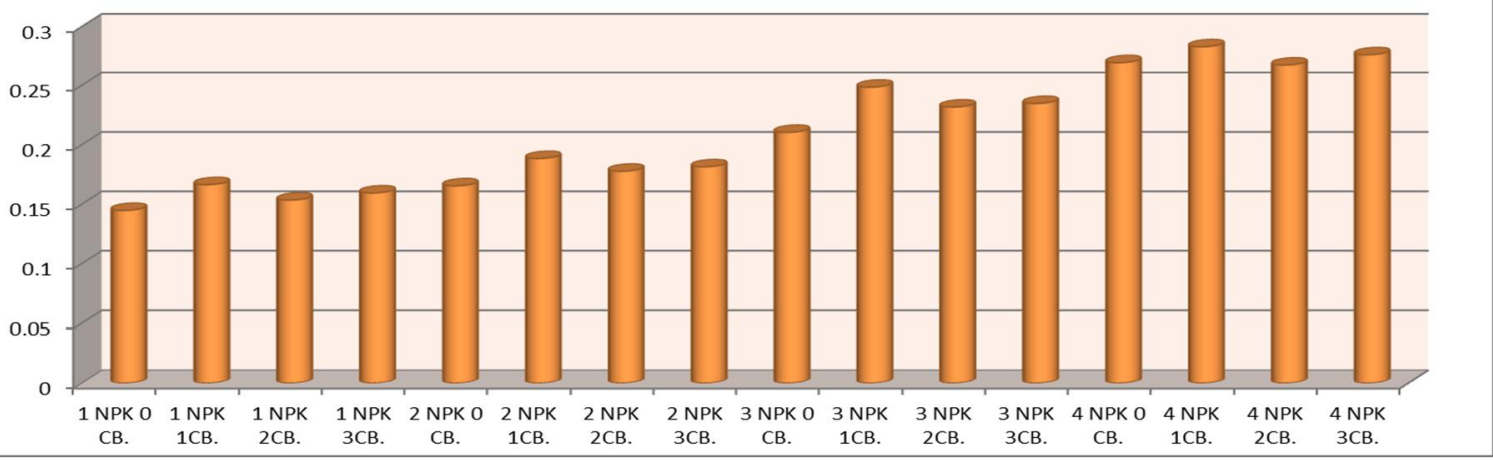

Fig. 4: Effect of cyanobacteria bio-fertilization and NPK fertilizatier on average volatile oil \%

\section{Effect of cyanobacteria bio-fertilization and NPK fertilizer on volatile oil compounds}

Results illustrated in Table 5 and Fig. (5, 6 and 7) showed the effect of different treatments (cyanobacteria bio-fertilization and NPK fertilizer) on volatile oil compounds. Gas chromatography analysis of the volatile oil compounds from rosemary essential oil herb during 2017 season, revealed the existence of 11 compounds from the identified compounds. The main components were Camphor (21.28\% to $25.41 \%)$, Limonene $(11.70 \%$ to $14.97 \%)$, Borneol $(8.20 \%$ to $11.96 \%)$ and $\alpha$-Pinene (7.45\% to $15.20 \%)$., Bornyl acetate $(7.16 \%$ to $13.22 \%)$ Linalool $(6.27 \%$ to $7.30 \%)$ and Terpineole (3.15\% to $4.30 \%$ ) other components were present in the amounts of $4 \%$ and less. Fig (5) Showed that the 4 NPK 1CB, 4 NPK 3CB, 4 NPK 2CB, 3 NPK 0 CB and 3 NPK 1CB treatments recorded great values from ( $\alpha$-Pinene, Camphene, $\beta$-Pinene and Limonene) than other treatments. While treatments 3 NPK 0 CB, 3 NPK 2CB, 4 NPK 0 CB, 4 NPK $1 \mathrm{CB}$ and 4 NPK 2CB gave the greatest values from Camphor Fig. (6), also 3 NPK 1CB, 3 NPK 3CB. And 3 NPK 2CB treatments increased Borneol content. Fig. (7) indicated that 4 NPK 0 CB, 3 NPK $2 \mathrm{CB}$ and 3 NPK 0 CB treatments boosted Bornyl acetate content. 
Table 5: Effect of cyanobacteria bio-fertilization and NPK fertilizer on volatile oil compounds during 2017 season.

\begin{tabular}{|c|c|c|c|c|c|c|c|c|}
\hline $\begin{array}{l}\text { Treatments } \\
\text { Compounds }\end{array}$ & $\begin{array}{c}\text { NPK } \\
\text { 0 CB }\end{array}$ & $\begin{array}{c}3 \text { NPK } \\
1 \text { CB }\end{array}$ & $\begin{array}{c}3 \text { NPK } \\
2 \text { CB }\end{array}$ & $\begin{array}{c}3 \text { NPK } \\
3 \text { CB }\end{array}$ & $\begin{array}{c}4 \text { NPK } \\
\text { 0 CB }\end{array}$ & $\begin{array}{c}4 \text { NPK } \\
1 \mathrm{CB}\end{array}$ & $\begin{array}{c}\text { 4 NPK } \\
2 \mathrm{CB}\end{array}$ & $\begin{array}{c}4 \mathrm{NPK} \\
3 \mathrm{CB}\end{array}$ \\
\hline$\alpha$-Pinene & 10.80 & 10.77 & 9.36 & 8.14 & 7.45 & 12.07 & 15.20 & 14.92 \\
\hline Camphene & 2.4 & 3.17 & 2.00 & 2.50 & 1.63 & 3.13 & 3.45 & 3.24 \\
\hline$\beta$-Pinene & 1.12 & 1.56 & 1.00 & 1.15 & 0.52 & 1.10 & 1.15 & 1.90 \\
\hline Limonene & 13.67 & 13.02 & 12.23 & 13.29 & 11.70 & 14.97 & $14 . .63$ & 13.70 \\
\hline Linalool & 7.16 & 6.70 & 6.27 & 7.00 & 7.30 & 6.40 & 6.38 & 6.90 \\
\hline Camphor & 25.41 & 21.28 & 24.30 & 22.02 & 25.41 & 23.66 & 23.47 & 22.80 \\
\hline Terpineole & 3.88 & 4.30 & 4.30 & 4.10 & 3.90 & 3.40 & 3.15 & 3.60 \\
\hline Borneol & 8.99 & 11.40 & 10.74 & 11.96 & 10.16 & 9.93 & 8.50 & 8.20 \\
\hline Bornyl acetate & 10.58 & 8.30 & 11.70 & 8.75 & 13.22 & 7.45 & 7.73 & 7.16 \\
\hline Eugenol & 2.39 & 2.36 & 1.63 & 2.37 & 3.00 & 2.24 & 2.01 & 2.00 \\
\hline$\beta$-Caryophyllene & 1.78 & 5.26 & 2.03 & 5.17 & 3.86 & 1.63 & 0.73 & 1.70 \\
\hline
\end{tabular}

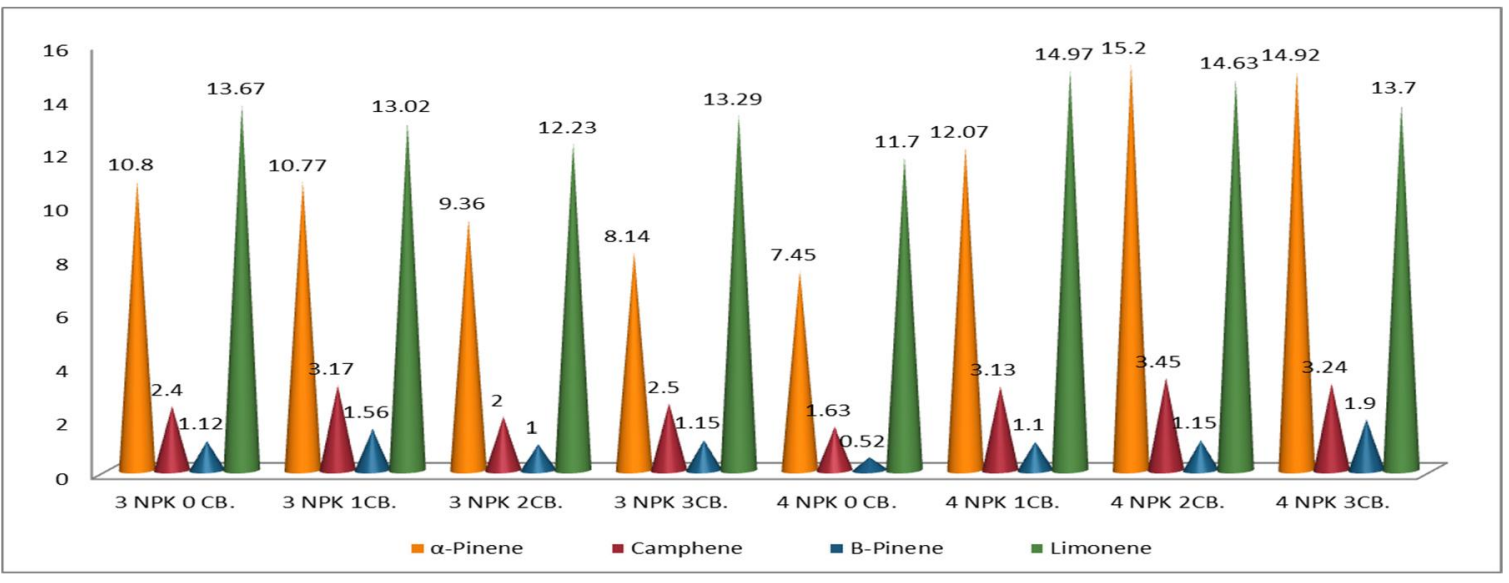

Fig.5: Effect of cyanobacteria bio-fertilization and NPK fertilizer on $\alpha$-Pinene, Camphene, $\beta$-Pinene and Limonene

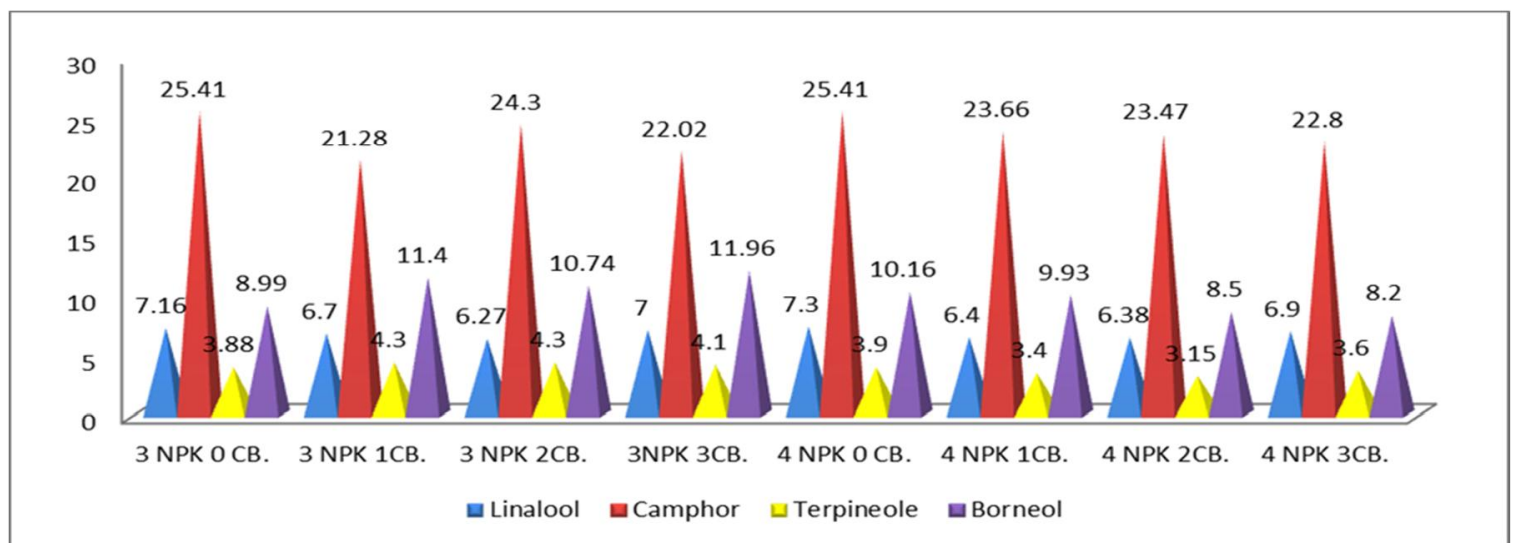

Fig. 6: Effect of cyanobacteria bio-fertilization and NPK fertilizer on Linalool, Camphor, Terpineole and Borneol 


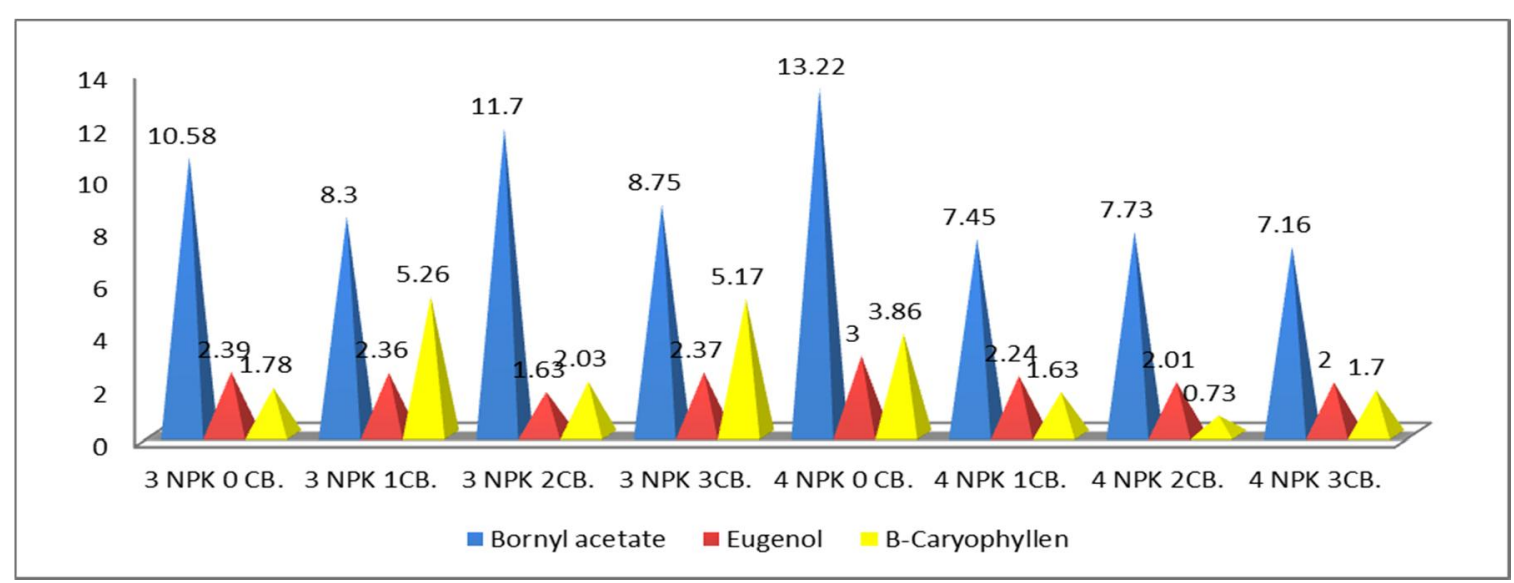

Fig. 7: Effect of cyanobacteria bio-fertilization and NPK fertilizer on Bornyl acetate, Eugenol and $\beta$ Caryophyllen

\section{Discussion}

The obtained results indicated that different concentrations of cyanobacteria bio fertilizers and NPK fertilizer ratios increased the vegetative growth; plant height, number of branches /plant and fresh and dry weights (g. /plant) of rosemary plants. NPK fertilization can be explained by the important roles played by the $\mathrm{N}, \mathrm{P}$ and $\mathrm{K}$ nutrients in the plant, which in turn affect plant growth. Nitrogen is a constituent of amino acids, enzymes and energy transfer materials such as chlorophyll, ADP and ATP, (Bidwell, 1974). Phosphorus is essential for cell division, development of meristematic tissues, carbohydrate transformation, photosynthesis and biological oxidation (Lambers et al., 2000). While, potassium functions as an osmotic, reacts synergistically with IAA and carbohydrates translocation, (Mengel and Kirkby, 1987). The increment in vegetative growth characters through NPK are in harmony with those reported by Law-Ogbomo and Law-Ogbomo, 2009 who found that NPK application significantly affected plant height and stem girth. Plant height was increased with successive increment in fertilizer application rate. This observation is in agreement with the findings of Babatola et al., (2006) who reported that increasing level of fertilizer application was observed to increase growth and yield of crops. Promotion of plant height as a result of NPK fertilization has been reported by prior researches (Alsafar and Al-Hassan, 2009, Hendawy and Kalid, 2011). Chemical fertilizer (NPK application) was most effective when it was applied at the full recommended dose recording the highest values of the vegetative; plant height, number of branches /plant and fresh and dry weights (g. /plant) of geranium plants traits compared to half dose of NPK (Sakr, et al., 2018). The increment recorded in the herb fresh weight of plants fertilized with chemical fertilizer is in agreement with the previous findings on Mentha piperita (Sheykholeslami, et al., 2015), The Cyanobacteria effect on crop yield was due to their release of various biologically active substances such as gibberellin, auxin, cytokinins (Whitton 2000 and Stirk et al. 2002). Cyanobacteria ( bio-fertilizers) can improve growth and crop yield since they add organic matter to soil (Zaccaro et al. 1999 and Maqubela et al. 2009), thus improving soil structure (De Caire et al. 2000; De Cano et al. 2002; Pandey et al. 2005; Issa et al. 2007; Obana et al.2007; Maqubela et al. 2009 and Saadatnia and Riahi 2009). The obtained results revealed that the application of cyanobacteria combined with 50 or $100 \%$ of the recommended dose of NPK fertilizer improved growth characters of marjoram (Origanum majorana) plants (Abdalla and Hendi 2014).

The increase in NPK contents of rosemary plants treated with different concentrations of NPK and cyanobacteria may be due to the availability of adequate amounts of $\mathrm{N}, \mathrm{P}$ and $\mathrm{K}$ in fertilized plants, Joubert and Lefranc (2008) mentioned that the algal active ingredients may stimulate nitrate reductase and other plant enzymes responsible for absorbing minerals and their transformation in the plant. Similar trend of increase in nutrient concentration was observed by Hegazi et al. (2010) on common bean plants and Ahmed et al. (2011) on grapevines. Nitrogen content varied from $1.55 \%$ to $1.94 \%$ while phosphorus content varied from $0.33 \%$ to $0.48 \%$ and potassium content varied from $2.30 \%$ to $2.90 \%$ of marjoram plants (Abdalla and Hendi, 2014) by the different treatment's levels of NPK fertilizers and cyanobacteria. 
The results showed that different concentrations of cyanobacteria bio fertilizers and NPK fertilizer ratios increased the essential oil \% and constituents of rosemary. These results were in harmony with Hussien (1995) who reported that NPK fertilization was more effective on dill volatile oil. It was established that essential oil content were increased with increasing NP fertilizer rates. Oil yield of peppermint were increased by the increase in NPK levels, Jeliazkova et al., (1999). NPK treatments produced the highest oil of garden thyme (Thymus vulgaris L.) compared with the control treatment ( Sharafzadeh 2011). Results recorded in all cuts of the two seasons showed that application of the different NPK treatments gave significantly higher essential oil \% and yield/ plant than the control in both cuts, mineral fertilization was most effective when applied at half dose for increasing the percentage of geranium essential oil in the herb moreover, full NPK treatment gave the highest values of essential oil yield/ plant in two cuts of both seasons, (Sakr, et al., 2018). The impact of NPK on increasing essential oil are consistant with those reported on Salvia officinalis, Salim(2006) and Cuminum cyminun Azizi, and Kahrizi, (2008). Moreover, the cyanobacterial foliar spray to $50 \%$ or $100 \%$ of the recommended dose NPK chemical fertilizers increased the essential oil components percent as a result of the improvement of growth characters of the treated marjoram plants (Abdalla and Hendi, 2014).

\section{Conclusion}

The optimum levels of cyanobacteria bio fertilizers and NPK fertilizer ratios for successful production were 4 NPK $1 \mathrm{CB}, 4$ NPK $2 \mathrm{CB}, 4$ NPK $3 \mathrm{CB}, 4$ NPK 0 CB, 3 NPK $1 \mathrm{CB}$ and 3 NPK 3CB gave the highest vegetative growth, essential oil \% and major compounds than other treatments, respectively. On the other hand treatments (2 NPK $1 \mathrm{CB}, 2 \mathrm{NPK} 3 \mathrm{CB}$ and $3 \mathrm{NPK} 0 \mathrm{CB}$ ) gave moderate values for vegetative growth and essential oil \% and major oil compounds, while the greatest treatment was (4 NPK 1CB) that recorded the highest values for vegetative growth, NPK contents and oil percentage when compared with other treatments under study conditions.

\section{References}

Abdalla, M. A. and D.M.G. Hendi, 2014. Effect of cyanobacterial foliar application and different levels of NPK fertilizer on growth, chemical composition and antioxidant activity of Origanum majorana L., Sci. J. Flo.\& Ornam. Plants, 1 (2): 171-186.

Ahmed, A.A., M.A. Megawer, A.E.M. Mansour, N.E. Ashour, and R.A.R. Eissa, 2011. Impact of fulvic acid and Spirulina platensis algae as a bio-organic fertilizers for flame seedless grapevines grown under sandy soil. Res. J. Agric. \& Biol. Sci., 7 (2): 287-293.

Alsafar, M.S. and Y.M. Al-Hassan, 2009. Effect of nitrogen and phosphorus fertilizers on growth and oil yield of indigenous mint (Mentha longifolia L., J. Biotech., 8(3): 380-384.

Al-Sereitia, M. R., K. M. Abu-Amerb and P. Sena, 1999. Pharmacology of rosemary (Rosmarinus officinalis L.) and its therapeutic potentials, Indian J. Experim Bio., 37: 124-131.

Azizi, K. and D. Kahrizi, 2008. Effect of nitrogen levels, plant density and climate on yield and quality in cumin (Cuminum cyminun). Asian J. Plant Sci., 7(8): 710-716.

Babatola, I. A., 2006. Effects of NPK 15:15:15 fertilizer on the performance and storage life of okra (Abelmuschus esculentus. Proceed. Hort. Soci. Nigeria Conf.: 125-128.

Bidwell, R.G., 1974. Plant Physiology. Macmillan Publishing Co. Inc., New York, U.S.A.

Bakirel, T., U. Bakirel, O. Ü. Keleş, S. G. Ülgen and H. Yardibi, 2008. In vivo assessment of antidiabetic and antioxidant activities of rosemary (Rosmarinus officinalis) in alloxan-diabetic rabbits. J. Ethnopharma., 116(1): 64-73.

Bozin, B., N. Mimica-Dukic, I. Samojlik and E. Jovin, 2007. Antimicrobial and antioxidant properties of rosemary and sage (Rosmarinus officinalis L. and Salvia officinalis L., Lamiaceae) essential oils. J. Agri \& Food Chemist., 55(19): 7879-7885.

British Pharmacopoeia, 1963. Determination of Volatile Oils in Drugs. The Pharmaceutical Press, 17 Bloomsbury Square, London, WC1.

Chapman, H. D. and P.F. Pratt, 1978.Method of Analysis for Soil and Water. $2^{\text {nd }}$ Ed., Chapter, 17:150-161. Uni. Calif. Div. Agric. Sci. USA.

Cheung, S. and J. Tai., 2007. Anti-proliferative and antioxidant properties of rosemary Rosmarinus officinalis. Oncology Reports, 17(6): 1525-1531. 
De Caire, G.Z., M.S. De Cano, M.C.Z. De Mule, R.M. Palmaand, K. Colombo, 1997. Exopolysaccharide of Nostoc muscorum (cyanobacteria) in the aggregation of soil particles. J. Appl. Phycol., 9:249-253.

De Caire, G.Z., M.S. De Cano, R.M. Palmaand and M.C.Z. De Mule, 2000. Changes in soil enzyme activities following additions of cyanobacterial biomass and exopolysaccharide. Soil Biol. Biochem., 32:1985-1987.

De Cano, S.M., Z.M.C. De Mule, Z.G. De Caire, R.M. Palma and K. Colombo, 1997. Aggregation of soil particles by Nostoc muscorum (Cyanobacteria. Int. J. Exp. Bot. 57:35-40.

De Cano M.M.S., G.Z. De Caire, M.C.Z. De Mulé and R.M. Palma, 2002. Effect of Tolypothrix tenuis and Microchaete tenera on biochemical soil properties and maize growth. J. Plant Nutr., 25:2421-2431.

Fashina, A. S., K. A. Olatunji and K. O. Alasiri, 2002. Effects of different plant population and poultry manure on yield of Ugu (Telfairia occidentalis) in Lagos State, Nigeria in Proceed. annual Conf..Hort. Soci. Nigeria (HORTON), 123-127.

Food Standards Agency, "Current EU approved additives and their E Numbers," https://www.food.gov.uk/science/additives/enumberlist.

Gomez, K.A. and A.A. Gomez, 1984) Statistical Procedure for Agricultural Research. $2^{\text {nd }}$ Ed.:8-22

Habtemariam, S., 2016. The Therapeutic Potential of Rosemary (Rosmarinus officinalis) Diterpenes for Alzheimer's Disease. Evidence-Based Complementary and Alternative Medicine, 2016, Article ID 2680409, pp14.

Hegazi, A.M., S.S.M. Mostafa and H.M.I. Ahmed, 2010. Influence of different cyanobacterial application methods on growth and seed production of common bean under various levels of mineral nitrogen fertilization. Nat. \& Sci., 8(11):183-194.

Hendawy, S.F. and K.A. Kalid, 2011. Effect of chemical and organic fertilizers on yield and essential oil of chamomile flower heads. J. Med. \& Arom. Plant Sci. Biotech., 5(1): 4348.

Hussien, M. S., 1995. Response of growth, yield and essential oil of coriander and dill to different nitrogen sources. Egypt. J. Hort. Sci., 22 (1): 1-10

Issa M. O., C. Défarge, Y. Le Bissonnais, B. Marin, O. Duval, A. Bruand, L.P. D'Acqui, S. Nordenbergand and M. Annerman, 2007. Effects of the inoculation of cyanobacteria on the micro structure and the structural stability of a tropical soil. Plant Soil, 290:209-219.

Jackson, M.L., 1973. Soil Chemical Analysis, Prentice Hall of India private limited, New Delhi, P. 498.

Jeliazkova, E.A., V.D. Zheljazkov, L.E. Craker, B. Yankov and T. Georgieva, 1999. NPK fertilizer and yields of peppermint, Mentha X piperita. Acta Hort., 502: 231-236.

Joubert, J.M. and G. Lefranc, 2008. Seaweed phytostimulants in agriculture: recent studies on mode of action two types of products from algae: growth and nutrition stimulants and stimulants of plant defense reactions. Book of abstracts: Biostimulators in Modern Agriculture. Warsaw, 7-8 February, 16.

Kennedy, D. O. and A. B. Scholey, 2006. The psychopharmacology of European herbs with cognition-enhancing properties. Current Pharma. Design, 12(35): 4613-4623.

Lambers, H., F.S. Chapin and T.L. Pons, 2000. Plant Physiology \& Ecology. Springer, Verleg Inc., New york, U.S.A.

Law-Ogbomo, K. E. and J. E. Law-Ogbomo, 2009. The Performance of Zea mays as influenced by NPK fertilizer application. Not. Sci. Biol., 1(1): 59-62.

Lowther, G.R., 1980. Using of a single $\mathrm{H}_{2} \mathrm{SO}_{4}-\mathrm{H}_{2} \mathrm{O}_{2}$ digest for the analysis of Pinus radiate needles. Commun. Soil Sci. Pl. Analysis, 11: 175-188.

Maqubela, M.P., P.N.S. Mnkeni, O. M. Issa, M.T. Pardoand and LP. .D'Acqui, 2009. Nostoc cyanobacterial inoculation in South African agricultural soils enhances soil structure, fertility and maize growth. Plant Soil, 315:79-92.

Mengel, K. and A. Kirkby, 1987. Principles of Plant Nutrition, 4th Ed. Inter Potash Institute, Bem, Switzerland.

Obana, S, K. Miyamoto, S. Morita, M. Ohmori, K. Inubushi, 2007. Effect of Nostoc sp. on soil characteristics, plant growth and nutrient uptake. J. Appl. Phycol., 19:641-646.

Obi, C. O., P. C. Nnabude and E. Onucha, 2005. Effects of kitchen waste compost and tillage on soil chemical properties and yield of Okra (Abelmuschus esculentus. Soil. Sci., 15:69-76. 
Pandey, K.D., P.N. Shukla, D.D. Giri and A.K. Kashyap, 2005. Cyanobacteria in alkaline soil and the effect of cyanobacteria inoculation with pyrite amendments on their reclamation. Biol Fertil. Soils, 41:451-457.

Saadatnia, H. and H. Riahi, 2009. Cyanobacteria from paddy fields in Iran as a biofertilizer in rice plants. Plant Soil Environ., 55:207-212

Saeed, I. M., R. Abbasi and M. Kazim, 2001. Response of maize (Zea mays) to nitrogen and phosphorus fertilization under agro-climatic condition of Rawalokol, Azad Jammu and Kaslim and Kashmir, Pak. J. Biological Sci., 4: 949-952.

Sakr, W. R.A., A.A. El-Sayed, A.M. Hammouda and F.S.A. Saad El Deen, 2018. Effect of NPK, aloe gel and moringa extracts on geranium plants. J. Hort. Sci. \& Ornam. Plants, 10(1): 1-16.

Salim, E.M.A. L., 2006. Effect of chemical, organic fertilizers and spraying with active dry yeast on growth, oil production and plant constituents of sage (Salvia officinalis L.) plants. M.Sc. Thesis, Fac. Agric., Cairo Univ., Egypt.

Sharafzadeh, S., 2011. Effect of nitrogen, phosphorous and potassium on growth, essential oil and total phenolic content of garden thyme (Thymus vulgaris L. Advanc. Environ. Biol., 5(4): 699 703.

Sheykholeslami, Z., M. Q. Almdari, S.Qanbari and M. Akbarzadeh, 2015. Effect of organic and chemical fertilizers on yield and yield components of peppermint (Mentha piperita L. Am. J. Exp. Agric., 6(4): 251-257.

Stefano, P., R. Dris and F. Rapparini, 2004. Influence of growing conditions, yield and quality of cherry. Fruit. J. Agric. \& Env., 2:307-309.

Stirk, W.A., V. Ördög, J. Van Staden and K. Jäger, 2002. Cytokinin and auxin like activity in cyanophyta and microalgae. J Appl. Phycol., 14:215-221.

Whitton, B.A., 2000. Soils and rice-fields. In: Whitton B.A and M. Potts (eds) The Ecology of Cyanobacteria. Kluwer Academic Publishers, Dordrecht, pp 233-255.

Yesil-Celiktas, O., C. Sevimli, E. Bedir and F. Vardar-Sukan, 2010. Inhibitory effects of rosemary extracts, carnosic acid and rosmarinic acid on the growth of various human cancer cell lines. Plant Foods for Human Nutrit., 65(2): 158-163.

Zaccaro, M.C., G.Z. De Caire, M.S. De Cano, R.M. Palmaand and K. Colombo, 1999. Effect of cyanobacterial inoculation and fertilizers on rice seedlings and postharvest soil structure. Comm Soil Sci. Plant Anal., 30:97-107. 